
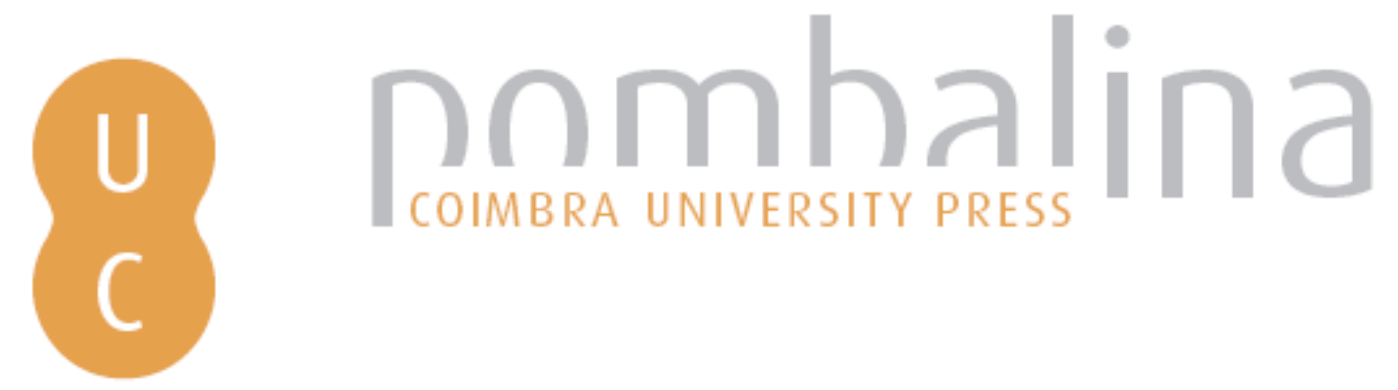

\title{
Prescribed fire experiences on crop residue removal for biomass exploitations and cost-benefits analysis, in mediterranean ecosystems
}

Autor(es): $\quad$ Rodríguez y Silva, Francisco; Ramón Molina, Juan

Publicado por: Imprensa da Universidade de Coimbra

URL

persistente: URI:http://hdl.handle.net/10316.2/44584

DOI: $\quad$ DOI:https://doi.org/10.14195/978-989-26-16-506_67

Accessed : $\quad$ 26-Apr-2023 16:08:25

A navegação consulta e descarregamento dos títulos inseridos nas Bibliotecas Digitais UC Digitalis, UC Pombalina e UC Impactum, pressupõem a aceitação plena e sem reservas dos Termos e Condições de Uso destas Bibliotecas Digitais, disponíveis em https://digitalis.uc.pt/pt-pt/termos.

Conforme exposto nos referidos Termos e Condições de Uso, o descarregamento de títulos de acesso restrito requer uma licença válida de autorização devendo o utilizador aceder ao(s) documento(s) a partir de um endereço de IP da instituição detentora da supramencionada licença.

Ao utilizador é apenas permitido o descarregamento para uso pessoal, pelo que o emprego do(s) título(s) descarregado(s) para outro fim, designadamente comercial, carece de autorização do respetivo autor ou editor da obra.

Na medida em que todas as obras da UC Digitalis se encontram protegidas pelo Código do Direito de Autor e Direitos Conexos e demais legislação aplicável, toda a cópia, parcial ou total, deste documento, nos casos em que é legalmente admitida, deverá conter ou fazer-se acompanhar por este aviso.

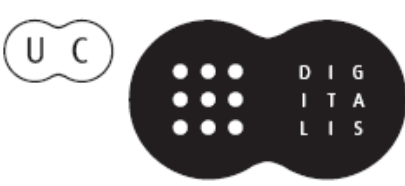




\section{ADVANCES IN}

\section{FOREST FIRE RESEARCH}

\section{8}

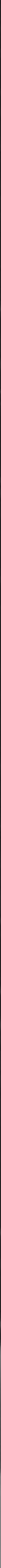




\title{
Prescribed fire experiences on crop residue removal for biomass exploitations and cost-benefits analysis, in mediterranean ecosystems.
}

\author{
Francisco Rodríguez y Silva*; Juan Ramón Molina \\ ${ }^{1}$ Forest Fire Laboratory. University of Córdoba (Spain), Edificio Leonardo da Vinci, Campus de \\ Rabanales, 14071, Córdoba, \{ir1rosif@uco.es*,jrmolina@uco.es\}
}

\begin{abstract}
The progressive increase in the use of prescribed fires, as a fire management technique for the prevention and reduction of the impact of forest fires, demands the development of new approaches. The generation of interesting utilities of this technique is not only related to the control of fuel load, but also to the creation and maintenance of operational scenarios. Biomass harvesting possibilities to rural development have led to a high woody biomass accumulation increasing potential wildfire severity. Mechanical thinning and prescribed burning practices could be jointly used to prevent large fires. The aim of this study was to assess burning treatment effectiveness in a medium-term planning (12 years) following mechanical thinning from biomass harvesting. An econometric model was designed to predict prescribed fires costs to reduce slash fuels, and as a consequence, the maximum efficiency or cost-benefit, mainly in strategic management or critical focal points.

Prescribed fires reduced available fuel in all fuel categories, mainly in fine dead fuel category. A costbenefit analysis to mitigate fire behavior was carried out using different burning severities. An efficiency burning management could reduce between $19.94 \%$ and $40.63 \%$ of the total costs in a medium-term planning (12 years). The most significant variables are related to fire severity (flame residence time) and stand characteristics, mainly canopy base height and remnant canopy cover. These variables allow us to predict costs per unit area based on different management alternatives. Managers can use this information to design technical prescription to achieve the targets while decomposed litter retention maintaining the soil properties and biodiversity under economic point of view. Understanding the most effective "burn window" should help better plan prescribed burning, in term of fire behavior, fuel consumption and the total budget that is necessary to reach the forest fires prevention and impact reduction in the forest landscapes in a medium-term planning.
\end{abstract}

Keywords: prescribed fire effectiveness, fire severity, fuel consumption, convective pruning; burning costs; presceibed fire planning

\section{Introduction}

Prescribed fires strategically allocated could be combined with traditional forest treatments, such as brush clearing, thinning and pruning, to reduce extent and severity of wildfires (Agee and Skinner, 2005). When thinning operations were made to biomass harvesting, a high load of dead fuel was appeared, independently of the skidding method. Thinned forests created mosaics of canopy gaps that provide an increment of the wind speed based on a reduction of draw coefficient (Molina et al., 2018). Prescribed fire treatments can reduce the available surface fuel, mainly 1- and 10-hr dead fuel generated by biomass harvesting, and as a consequence, the probability to transition to crown layer. Prescribed fires under these biomass harvesting stands should be achieved by a "burn window" which included tree mortality and convective heating.

There are some new sources of data on costs of burnings, prevention in costs or factor influencing the cost variability (Rodríguez y Silva, 2018). The total costs of prescribed fires includes burn preparation, burn, smoke management, general overhead and post-fire evaluation (Cleaves et al., 2000). Costs can vary depending on fire complexity, objectives, operational efficiency and unit size. 
In spite of one American study showed that burn objective was not a significant cost factor in prescribed fires (González-Cabán, 1997), the objectives of the burn could modify safety precautions based on fire severity (Rodríguez-Cabán and McKetta, 1986; Vega et al., 2001). Unit size is other of the most important factors; larger units have smaller costs. Costs also vary with the irregularity shape of the unit but it can be necessary in strategic management points. In stands areas, managers can incurs higher costs by using slower and less severe ignition techniques than head-fire.

Assessing the cost-effectiveness of fuel treatments presents many challenges, mainly in prescribed fires (Omi et al., 1999). Although prescribed fire treatments generally are lower in cost than other fuel treatments (i.e., mechanic al thinning and pruning), fire also is more variable in its effects depending on fire severity. Shaded fuelbreaks must be created in the context of the landscape within which they are placed (Agee et al., 2000). Fuel accumulation rate frequently limits prescribed fire effectiveness to a short post-treatment period (2-4 years) (Fernandes and Botelho, 2003). Prescribed fire effectiveness should be based on the mitigation or reduction of both surface and crown fire behavior. The effectiveness of a prescribed fire may be obscured by forest structure, fuel moisture, weather conditions and ignition patterns (Van Mantgem et al., 2016). Although prescribed fires reduced surface fuels, it is possible that coarse woody fuel and needles may be high from branches from convective heating (Agee and Lolley, 2006; Molina et al., 2018).

This work presents the results of combinations of biomass harvesting thinning and burning treatments. In this sense, this paper aims at developing an economic approach to identify the effects of prescribed fires on slash reduction based on a medium-term sampling (12 years). By extending prescribed fire study from the original point of fuel consumption, we have incorporated economic medium-term approach in order to identify effects of each fire severity on prescribed fire effectiveness.

\section{Material and methods}

\subsection{Study area}

The study was conducted in four study areas (Riofrio area, Sierra Alta area, Parrillas area and Velefique-Senés area) located in southern of Spain (Figure 1), occupying a sampling area about 100 ha. They are located in two regional administrative divisions (Andalusia and Castilla la Mancha) covering three 1 administrative provinces (Córdoba, Almería and Ciudad Real). All of these provinces are characterized by a Mediterranean climate with a pronounced dry period and summer temperature usually reaches $40^{\circ} \mathrm{C}$.

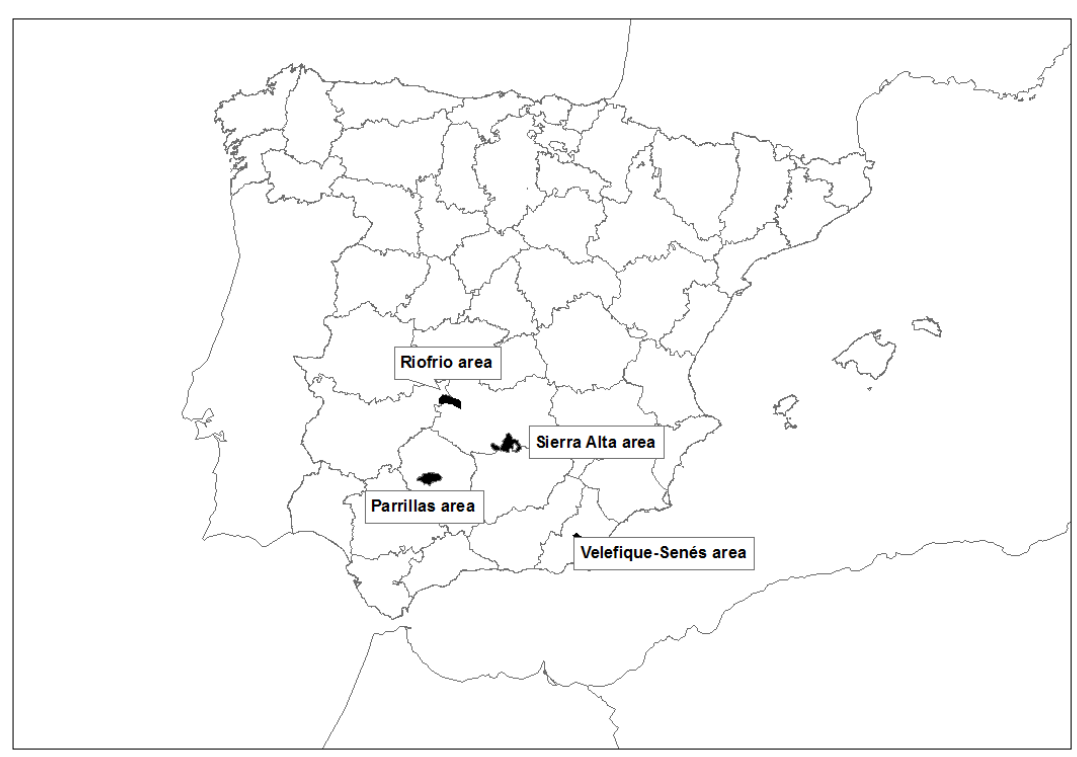

Figure 1 - Study areas location

The study was undertaken in three Pinus pinaster areas (Riofrio area, Sierra Alta area and Parrillas area) and one Pinus nigra area (Velefique-Senés area). Differences in stand characteristics (density, canopy base area, crown height,...) were shown among the different study areas.

The study area has been management from the viewpoint of forest biomass harvesting according to periodic thinning operations. Fire management agency tries to remove the important load of slash on 
different stands involved in biomass harvesting using burning. Mechanical selected thinning followed by prescribed fire was tested in combination. Stands were exploited at least two years before first burning in order to get a minimum dynamics on undergrowth fuel.

Total costs of these prescribed fires have included burn preparation (planning redaction, perimeter cleaning, pruning,...), burn (ignition, safety and liquidation resources) and post-prescribed fire evaluation (surface and crown layers). A spreadsheet was used by forest managers to include every costs. While planning redaction and post-fire evaluation was valued using number of required hours (technicians), preparation and burn resources were valued using the official cost per hour (Andalusia Government). The price of gasoil was included according to a filling-station' bill.

\subsection{Sampling design}

The data sampling collected both environmental information and fuel variables to assess prescribed fire effectiveness. A random stratified inventory was made according to proportional allocation. The forest inventory was carried out in circular plots of 1,000 $\mathrm{m} 2$ across the different stands incorporating variables diameter at breast height, tree height and basal area. The characterization of surface fuel was conducted though destructive transects using the line-intercept method (Stephens and Modhaddas, 2005). Fuel load was calculated in sampling plots with areas of $1 \times 1 \mathrm{~m}$ showing fuel load by category (live and dead) and particle size (expressed in 1-, 10-, $100 \mathrm{~h}$ time-lag). Separate live and dead fuel by particle size was needed to identify fuel moisture. Each sample underwent a 72-hours drying process in an oven set at $70^{\circ} \mathrm{C}$, at which this time, fuel weights were constant.

Thermocouples type $\mathrm{k}$ ( $50 \mu \mathrm{m}$ diameter) were placed inside the surface and crown layers. We could obtain spread rate, maximum temperature and flame residence time from these data (Table 1). Two video cameras and an infrared camera were also used to determinate flame length.

Table 1 - Equations for fire behavior modeling

\begin{tabular}{|l|l|}
\hline Variable & Equation \\
\hline Flame length & $\mathrm{L}=\mathrm{F} / \sin \mathrm{A}$ \\
\hline Fire-line intensity & $\mathrm{I}=(\mathrm{HC} * \mathrm{AF} * \mathrm{SR})$ \\
\hline Heat per unit area & $\mathrm{H}=\mathrm{HC} * \mathrm{AF}$ \\
\hline
\end{tabular}

where $\mathrm{L}$ is the flame length expressed as $\mathrm{m}, \mathrm{F}$ is the flame height measured in $\mathrm{m}, \mathrm{A}$ is the flame angle identified in ${ }^{\circ}$, I is the fire-line intensity expressed as $\mathrm{kW} / \mathrm{m}$, AF is the available fuel load measured as $\mathrm{kg} / \mathrm{m}^{2}$, SR is the spread rate expressed as $\mathrm{m} / \mathrm{s}, \mathrm{H}$ is the heat per unit area expressed as $\mathrm{kJ} / \mathrm{m}^{2}, \mathrm{HC}$ is the heat of combustion $(18,500 \mathrm{~kJ} / \mathrm{kg})$ and $\mathrm{AF}$ is the available fuel load measured as $\mathrm{kg} / \mathrm{m}^{2}$. A basic value of $18,500 \mathrm{~kJ} / \mathrm{kg}$ can be used for the heat of combustion or HC (Albini, 1976).

ANOVA analysis and Tukey HSD test were performed to identify if significant differences ( $\mathrm{p}<$ 0.05 ) existed in the dynamics of surface fuel load by categories and canopy base height according to each prescribed fire. In a similar way, a temporal horizon planning of 12 years would be used to evaluate if significant differences $(\mathrm{p}<0.05)$ existed in the economic effectiveness of each prescribed fire. Multiple regression analysis was used to develop fire prescribed cost from environmental and burning variables. In some cases, a Principal Component Analysis (PC) allowed us to reduce a smaller set of variables.

\section{Results}

Total cost of prescribed fires in Sierra Alta area ranged from $398.43 € /$ ha to $1,445.5 € /$ ha, with an average value of $911.07 € /$ ha. While dead fuel moisture ranged from 11\% (burning 2016 in Sierra Alta 
II) to 17\% (burning 2011 in Sierra Alta II), flame length varied between 0.3-0.5 (burning 2016 in Sierra Alta I) to 0.8-0.9 (burning 2011 in Sierra Alta II).

Firstly, we analyzed surface fuel in Sierra Alta I during seven years: before a first moderate burning (2009), five years after the first burning and before the second prescribed fire, and one year postsecond severe burning (Figure 2). The first burning did not reduce the $1 \mathrm{~h}$ time-lag dead fuel and even it promoted the proliferation of live fuel $(0.17 \mathrm{t} / \mathrm{ha})$. The amount of $10 \mathrm{~h}$ time-lag dead fuel varied significantly after the first burning. At the second burning, all of the categories decreased in relation to the rest of the temporal monitoring.

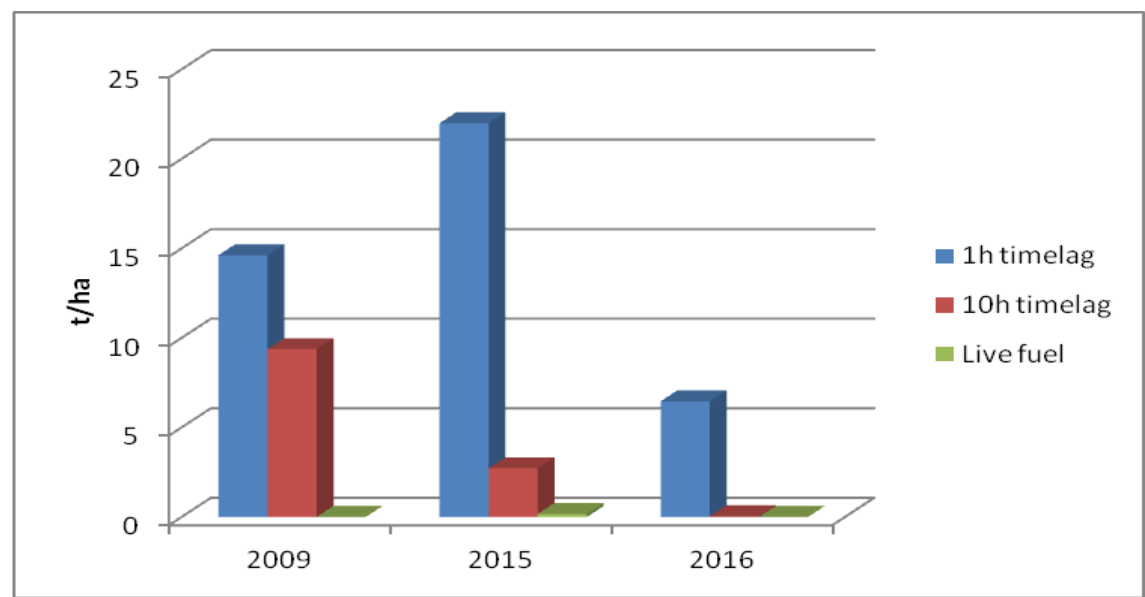

Figure 2 - Temporal evolution of surface fuel model in Sierra Alta I

We analyzed surface fuel in Sierra Alta II during six years: before first moderate burning (2010), four years post-first burning and before the second severe prescribed fire, and one year post-second burning (Figure 3). The first burning reduced dead fuel, mainly the $10 \mathrm{~h}$ time-lag fuel. There were not significant differences between before and after the second prescribed fire in relation to $1 \mathrm{~h}$ time-lag dead fuel. In this case, live fuel appeared before the second burning $(0.08 \mathrm{t} / \mathrm{ha})$.

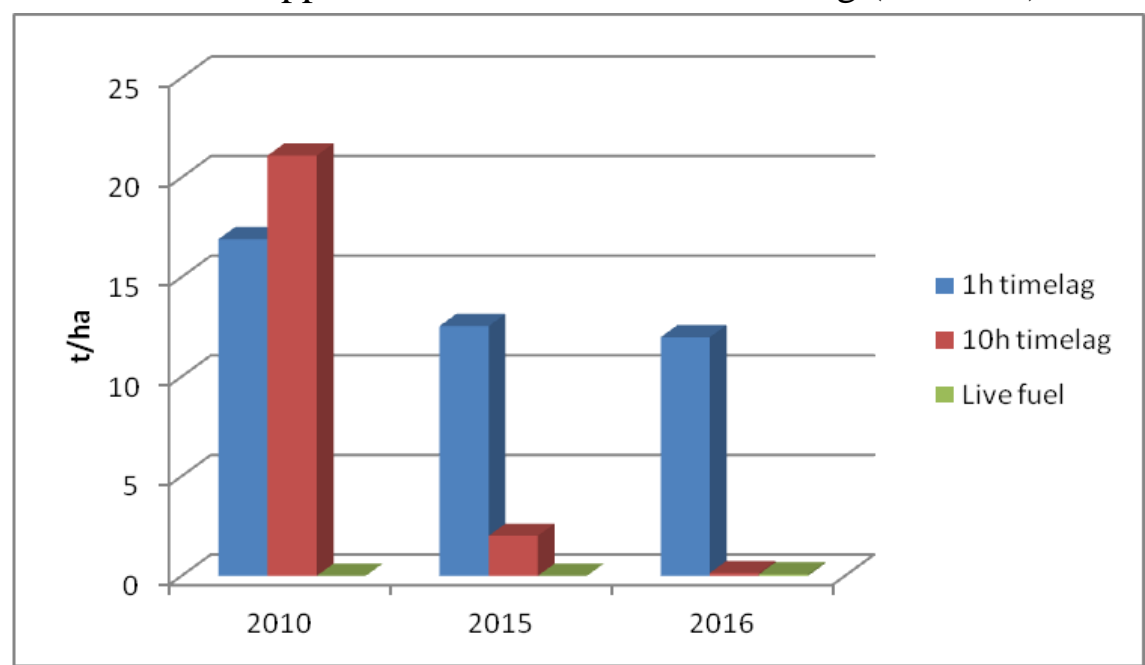

Figure 3 - Temporal evolution of surface fuel model in Sierra Alta II

The crown layer was evaluated based on canopy base height and crown scorch o crown reduction (available fuel load on canopy for crown fire). In Sierra Alta I, while a low crown height was affected 
by convective heating in the first burning, more than $50 \%$ of the crown was affected in the second burning (Figure 4). Canopy base incremented from $3 \mathrm{~m}$ to $7.12 \mathrm{~m}$ after the second burning.

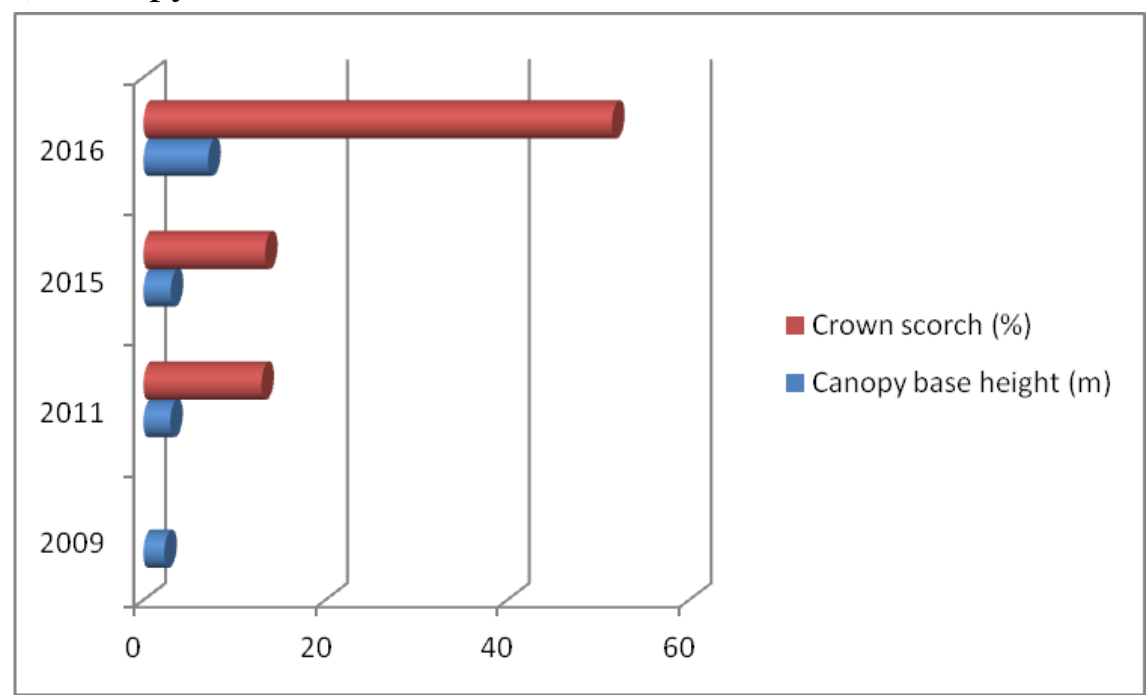

Figure 4 - Temporal evolution of crown fuel model in Sierra Alta I

In Sierra Alta II, there was a smaller affected crown height (less than $5 \%$ of the crown) than in Sierra Alta I. However, in the second burning treatment the crown scorch increased at $64.24 \%$ (Figure 5). Therefore, canopy base height was higher than in Sierra Alta I after the second burning.

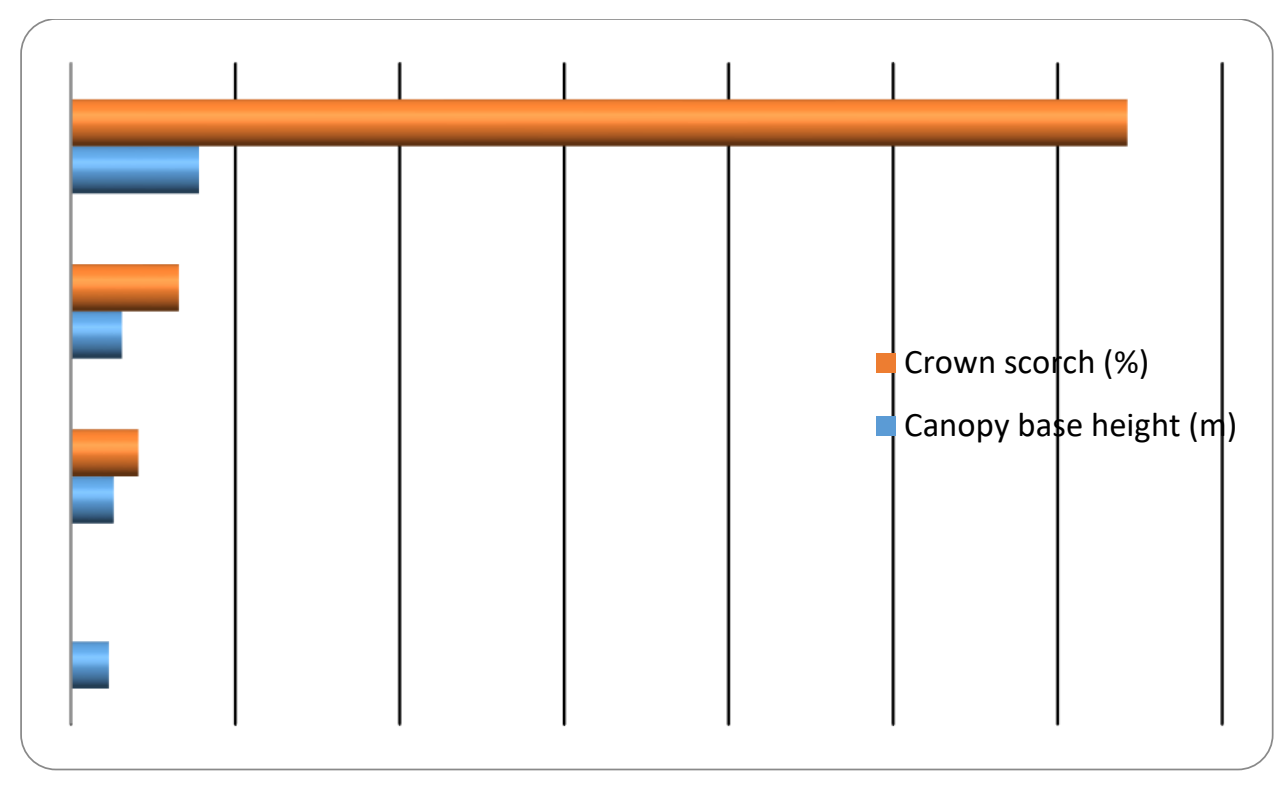

Figure 5 - Temporal evolution of crown fuel model in Sierra Alta II

In some severe convective prunings (burnings with crown scorch upper than 50\%), the reduction of canopy cover promotes the proliferation of live and very flammable fuel. In only one year, understory grew $0.08 \mathrm{t} / \mathrm{ha}$ due to the sun exposure because of the affectation of $64.24 \%$ of the tree crowns (Sierra Alta II) (Figure 6). In Parrillas area, live fuel grows exponentially (Figure 7), reaching its maximum development in a severe burning where remnant canopy cover was lower than $40 \%$. In three years, live fuel increases to $3.64 \mathrm{t} / \mathrm{ha}$ modifying the original fuel model (needles fuel model to a understory fuel model). Therefore, in Parrillas area, a higher tree mortality has been identified by more 
severe burnings (higher flame residence times). In this sense, tree mortality ranged from $6.37 \%$ (light burning) to $27.47 \%$ (severe burning). Although biomass harvesting thinning was similar, and as a consequence, the remnant canopy cover $(47.18 \%$ and $48.69 \%$, respectively), tree mortality promoted gaps where live fuel was established, modifying the original fuel model. Furthermore, it highlights the better condition of Pinus pinaster regeneration in light burning (3,392 seedlings/ha) than in severe burning (633 seedlings/ha) after three years.

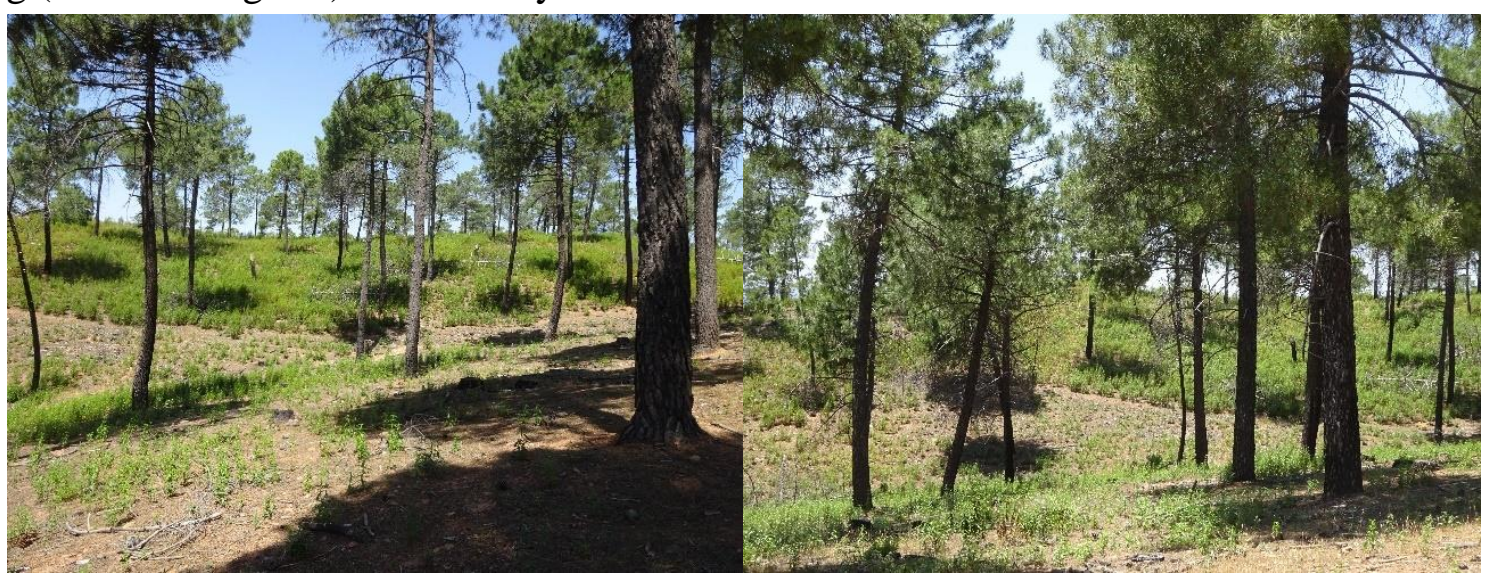

Figure 6 - Temporal evolution of two different burnings according to its fire severity

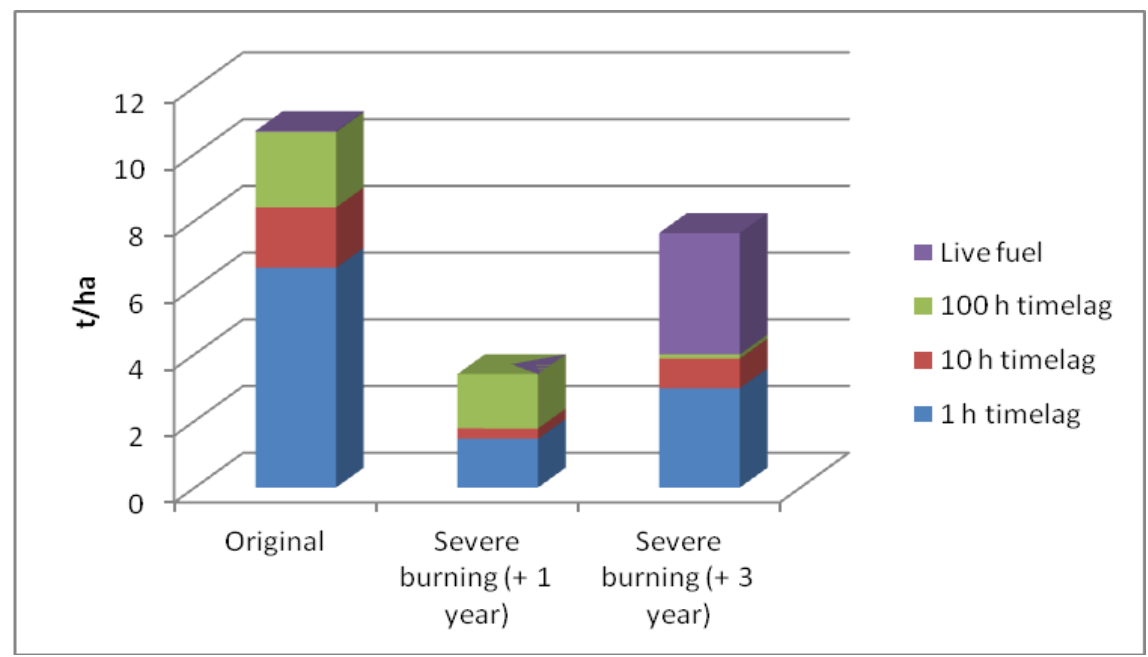

Figure 7 - Temporal evolution of severe burning in Parrillas area

Significant differences were found in Riofrio area under three different fire severities (Table 2). In this area, tree mortality ranged from $0.94 \%$ (similar to $0.63 \%$ of natural area) to $12.21 \%$ according to fire severity (Figure 8). Live and flammable fuel increased between 25 and $35 \%$ in more severe prescribed fires in only three years due to the canopy gaps.

Table 2 - Fuel load generated by three different fire severities in Riofrío area

\begin{tabular}{|c|c|c|c|}
\hline Fuel type & Severity A & Severity B & Severity C \\
\hline Needles (t/ha) & $5.37^{\mathrm{a}}$ & $4.37^{\mathrm{a}}$ & $7.46^{\mathrm{b}}$ \\
\hline 1h time-lag (t/ha) & $1.09^{\mathrm{a}}$ & $0.77^{\mathrm{b}}$ & $1.43^{\mathrm{c}}$ \\
\hline 10h time-lag (t/ha) & $0.44^{\mathrm{a}}$ & $0.70^{\mathrm{b}}$ & $1.45^{\mathrm{c}}$ \\
\hline 100h time-lag (t/ha) & $1.64^{\mathrm{a}}$ & $0.40^{\mathrm{b}}$ & $1.35^{\mathrm{a}}$ \\
\hline Live fuel & $0^{\mathrm{a}}$ & $0.32^{\mathrm{b}}$ & $0^{\mathrm{a}}$ \\
\hline Total & $8.55^{\mathrm{a}}$ & $6.57^{\mathrm{a}}$ & $11.70^{\mathrm{b}}$ \\
\hline
\end{tabular}



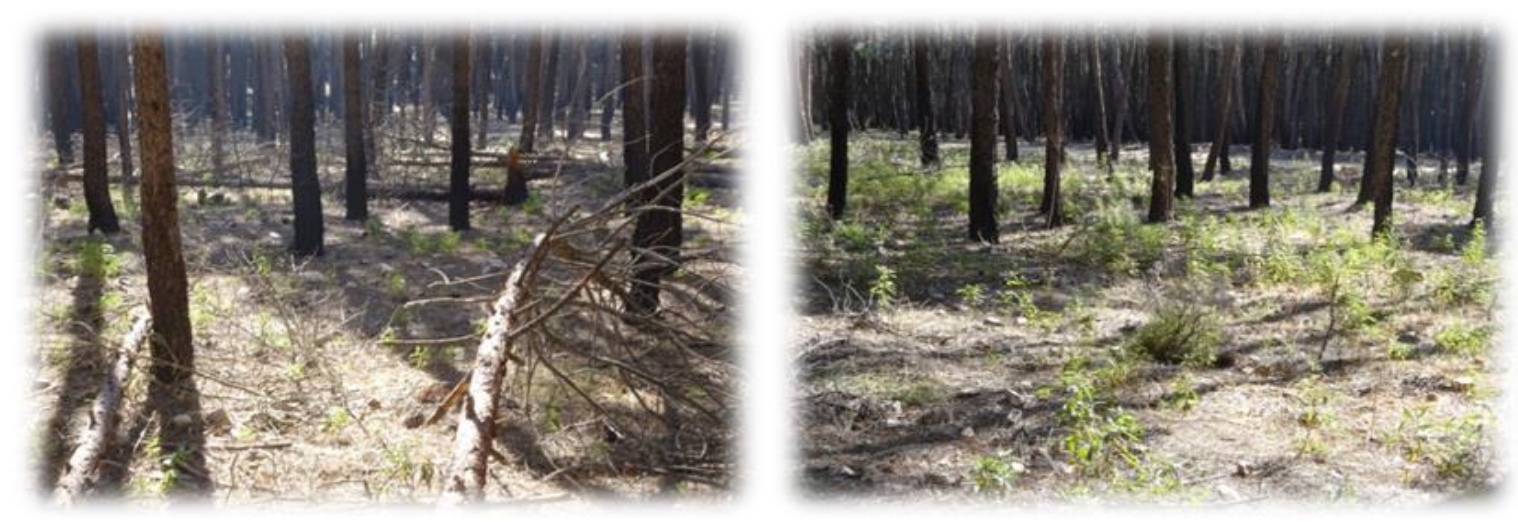

Figure 8 - Temporal evolution of severe burning in Riofrio area. Tree mortality and the proliferation of live fuel in three years can be observed

In Velefique-Senés area, most of the preliminary results were tested and validated. We can note the lower difference in the remnant condition of the surface and crown fuels due to canopy base height and the large presence of dead fuel before the burning. In this area, prescribed fire costs increases to $1,040-1,400 € /$ ha with perimeter treatment without inclusion.

\section{Discussion}

Despite the surface fuel reduction was very high in all burnings (ranging from 59.07\% to 86.18\%), needles and coarse woody fuel fell from canopy due to the convective heating (Agee and Lolley, 2006). Fire severity was one of the most important parameter in prescribed fire effectiveness (Van Mantgem et al.. 2016). When the first burning severity was moderate, a large of amount of needles fell on the ground (Sierra Alta I) showing a fuel load close to the original fuel model in six years. In these cases, it is necessary a second burning in a short-term period to mitigate crown fire probability. On the other hand, if fire severity is lower, the burning treatment may be effective six years later. Although the most efficient "burn window" was identified by a litter moisture ranged from 9\% to 15\%, (Molina et al., 2018), it only considered surface fuel consumption. If we took into account the convective heating and pruning generated to canopy trees, these conditions would be reduced between $13 \%$ and $15 \%$. Litter moisture upper than $15 \%$ did not reach the reduction targets of the burning, and as a consequence, it limits prescribed fire effectiveness.

All canopy cover changes, mainly stand density and canopy cover fraction, have provided an increment of the wind speed based on a reduction of draw coefficient. The wind speed was taken from two anemometers. located at treeless area and inside of each burn the day before burning without influence of fire and smoke. Drag coefficient ranged from 0.34 to 0.55 for the studies areas based on stand density and crown condition at the burning moment. Changes in drag coefficient have a direct influence in spread rate. and as a consequence. in fire-line intensity. Changes in dead fuel moisture were only observed by the comparison between canopy covers less than $75 \%$ and canopy covers were higher than this reference value.

Prescribed fire effectiveness was identified based on the mitigation or reduction of both surface and crown fire behavior. Prescribed fire treatments reduce the available surface fuel mainly 1- and 10-hr dead fuel generated by biomass harvesting. However, coarse woody fuel and needles were fallen from branches increasing the surface fuel load in a medium term planning. If the amount of canopy fuel on the ground is high, other burning should be made to mitigate the probability to the transition to crown fire. This fact increases considerably the costs of prescribed fires in a medium-term planning. We used Visual Behave software (Figure 9) to analyze the effects of prescribed fires on fire behavior. If the transition from surface fire to crown fire is not possible (Van Wagner, 1977), burning treatment was 
considered effective. Nevertheless, surface fire behavior was simulated taken into account that flame length should be lower than $2.5 \mathrm{~m}$ and spread rate should be lower than $7.5 \mathrm{~m} / \mathrm{min}$.

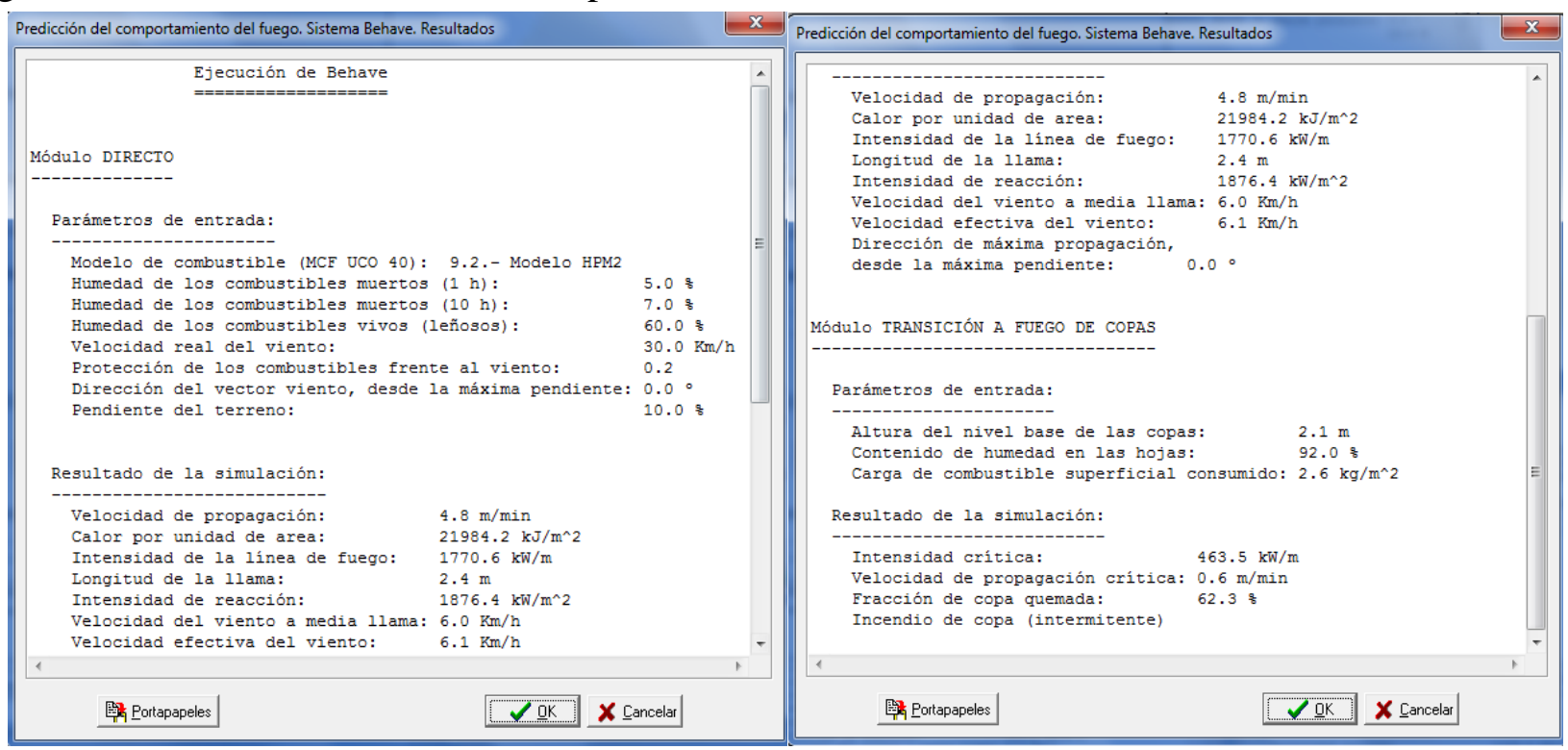

Figure 9 - Simulation of the effects of prescribed fire using Visual Behave software

A temporal planning of 12 years was used according to the context of the landscape within the duration of two periodical fire planning in Spain. Some studies limits prescribed fire effectiveness to a short post-treatment period (2-4 years) (Fernandes and Botelho. 2003). In our approach, this effectiveness varied based on burning behavior and stand characteristics. The cost-benefit of a prescribed fire planning in a medium-term (12 years) may be obscured by flame residence time, canopy base height and remnant canopy cover of the first burning. However, flame residence time is very difficult to measure "in situ" because of the smoldering process. In this case, we have modified the original model in spite to reduce its coefficient of determination and to increase the standard error including variables most easy to collect in field burnings. The final cost of prescribed fire management in a medium-term planning responds to the following econometric equation:

Cost fire planning $(€ / \mathrm{ha})=\alpha_{1} \mathrm{FS}_{1}+\alpha_{2} \mathrm{CBH}_{1}+\alpha_{4} \mathrm{CC}_{1}+\alpha_{5} \mathrm{FS}_{2}$

where $\mathrm{FS}_{1}$ is the fire severity classified based on 4 levels according to flame length $(\mathrm{m})$ and spread rate $(\mathrm{m} / \mathrm{min})$ in the first burning, $\mathrm{CBH}_{1}$ is the canopy base height before the first burning, $\mathrm{CC}_{1}$ is the canopy crown cover (\%) between six and nine months after the first burning, $\mathrm{FS}_{2}$ is the fire severity classified based on 4 levels according to flame length $(\mathrm{m})$ and spread rate $(\mathrm{m} / \mathrm{min})$ in the second burning.

As an example of the econometric model application, we have analyzed the cost of prescribed fire management for two real alternatives of burning of four areas based on its fire severity and according to stand characteristics (Table 3). There were significant differences in Parrillas, Riofrio and Sierra Alta areas between one and another alternative of management. In this sense, cost reduction ranged from $454.39 € /$ ha to $936.14 € /$ ha. However, costs of Velefique-Senés area were very similar based on the low canopy base height, the higher fire vulnerability of Pinus nigra and the high decomposed litter of this fuel model. 
Table 3 - Cost of prescribed fire planning (12 years) for the study areas

\begin{tabular}{|l|c|c|c|}
\hline $\begin{array}{c}\text { Cost of prescribed fire } \\
\text { planning (€/ha) }\end{array}$ & $\begin{array}{c}\text { Alternative A } \\
(\boldsymbol{\epsilon} / \mathbf{h a})\end{array}$ & $\begin{array}{c}\text { Alternative B } \\
(\boldsymbol{€} / \mathbf{h a})\end{array}$ & $\begin{array}{c}\text { Cost reduction } \\
(\boldsymbol{\%})\end{array}$ \\
\hline Parrillas Area & $2,303.89$ & $1,367.75$ & 40.63 \\
\hline Riofrio Area & $2,278.82$ & $1,824.43$ & 19.94 \\
\hline Sierra Alta Area & $2,541.87$ & $1,630.8$ & 35.84 \\
\hline Velefique-Senés Area & $2,432.82$ & $2,407,75$ & 1.03 \\
\hline
\end{tabular}

The use of Geographic Information System (GIS) and fire simulators in fire prevention planning provides flexibility when finding strategy locations to prescribed fires and increases the dynamisms of periodical planning in the case of use different alternatives. The optimal selection of prescribed fire planning increases the economic efficiency of preventive treatments under a worldwide scenario of budgetary constraints. In this sense, in some biomass harvesting areas (Parrillas, Riofrio, Sierra Alta), an efficiency management could help to facilitate an increase between $19.94 \%$ and $40.63 \%$ of the preventive treated area in a medium-term management.

\section{Conclusions}

Given the current budgetary constraints, measures for economic efficiency acquire a keystone role. In this sense, an adequate management of prescribed fires requires the medium-term monitoring of the surface and crown fuels. Prescribed fires on biomass harvesting scenarios could fulfill a meaningful fire prevention function based on fuel consumption and economic efficiency of burning treatment. This research provides a easy tool to evaluate in a medium-term period how to invest the available fire resources. It aids managers in developing prescribed fire planning in a sustainability and efficient way to mitigate potential fire impacts.

\section{References}

Agee J., Bahrob B, Finney Ma, Omi D., Skinner S., Van Wagtendonkg, Weatherspoonh P (2000), The use of shaded fuelbreaks in landscape fire management. Forest Ecology and Management 127, 5566.

Agee JK, Skinner C (2005) Basic principles of forest fuel reduction treatments. Forest Ecology and Management 211, 83-96.

Agee JK, Lolley MR (2006). Thinning and prescribed fire effects on fuels and potential fire behavior in an eastern Cascades forest. Fire Ecology 2(2), 142-158.

Cleades DA, Martínez J, Haines T (2000) Influences on Prescribed Burning Activity and Costs in the National Forest System. General Technical Report SRS-37.

Fernandes P, Botelho H (2003). A review of prescribed burning effectiveness in fire hazard reduction. International Journal of Wildland Fire 12(2), 117 - 128

González-Cabán A, McKetta C (1986) Analyzing fuel treatment costs. Western Journal of Applied Forestry 1(4), 116-121.

González-Cabán A (1997). Managerial and Institutional Factors Affect Prescribed Burning Costs. Forest Science 43, 535-543.

Molina JR, García JP, Fernández JJ, Rodríguez y Silva F (2018) Prescribed fire experiences on crop residue removal for biomass exploitations. Application to the maritime pine forests in the Mediterranean Basin. Science of the Total Environment 612, 63-70 
Omi P. Rideout D, Botti S (1999) An Analytical Approach for Assessing Cost-Effectiveness of Landscape Prescribed Fires. General Technical Report PSW- GTR-173. 237-241.

Rodríguez y Silva F, Hand M (2018) Modelling an econometric function to predict prescribed burning costs. Proceedings of Fire Continuum Conference. Missoula, Unites Stated.

Rodríguez y Silva F, Molina JR, Carmona JF (2010) Manual Técnico de Aplicaciones Informáticas para la Defensa contra Incendios Forestales. Servicio de Publicaciones Forestales. MANPAI XXI, Córdoba.

Stephens SL, Moghaddas J (2005) Experimental fuel treatment impacts on forest structure potential fire behavior and predicted tree mortality in a California mixed conifer-forest. Forest Ecology and Management 215, 21-36.

Van Mantgem PJ, Lalemand L, Keifer M, Kane J (2016) Duration of fuels reduction following prescribed fire in coniferous forests of U.S. national parks in California and the Colorado Plateau. Forest Ecology and Management 379, 265-272.

Van Wagner CE (1977) Conditions for the start and spread of crown fire. Canadian Journal of Forest Research 7, 23e34.

Vega JA, Pérez-Gorostiaga P, Cuñas P, Fontúrbel T, Fernández C (2001) Manual de Quemas Prescritas para Matogueiras de Galicia. Colección Técnica Medio Ambiente. Xunta de Galicía. Pontevedra. 